\title{
FORMALISM AND THE ACADEMIC FOUNDATION OF TURKISH ART IN THE EARLY TWENTIETH CENTURY
}

The modern conception of the history of Anatolia (or "Lands of Rum") during the four centuries between the Battle of Manzikert in 1071 and the conquest of Constantinople in 1453 is constructed on a simple sequence of three dynastic periods-Seljuk, Beylik, and Ottoman. Providing a rudimentary navigational chart for periodization, this tripartite sequence in fact allows only limited visibility of the complex social, political, and cultural vistas of the extended period during which the Turkish and Muslim settlement of Anatolia took place. The generalized definition and application of medieval dynastic terms are fraught with confusion. Thus, "Seljuk" is frequently used as a catchall term referring to the historical and cultural legacy of the post-Manzikert period within the borders of modern Turkey. It can subsume, in the name of terminological convenience, such early Turkish (or Turkmen) dynasties as the Saltuqids, the Mengujekids, the Danishmendids, the Artuqids, and the Armanshahs, among others. The confusion arises mainly from the fact that the label "Seljuk" is identified dynastically with the Seljuk sultanate of central Anatolia but chronogeographically with the period between the twelfth and fourteenth centuries and the entire configuration of Muslim Turkish dynasties spread across much of the country. Moreover, the term "Seljuk," in its blanket application to the land of Anatolia during the medieval era, simply excludes non-Turkic or non-Muslim cultures and polities, both of the Byzantines-based also in Nicaea and Trebizond-and of the Kingdom of Armenian Cilicia.

With the breakup of the Seljuk sultanate at the turn of the fourteenth century and the rise of a new constellation of Muslim Turkic dynasties (beyliks), an even more complicated political phase emerged in Anatolia. The period between approximately 1300 and 1500 is covered by the umbrella term "Beylik," which, like its sibling term "Seljuk," imposes a generalized view of this complexity while impeding finer distinctions and differentiations to be drawn among the various beyliks. More importantly, the collective application of the terms "Seljuk" and "Beylik" and their effective limitation by the modern borders of Turkey have encouraged an introverted and monocultural perspective on the history of this period. Medieval Anatolia is conceived of as an island disconnected from the rest of the region, so that the complex dynamics of the process of settlement, which lasted well into the fifteenth century, are disregarded. The indiscriminate applications of the terms "Seljuk" and "Beylik" thus amount to a deliberate compression of the contours of a particularly undulating history. In other words, in the conventional and wholesale deployment of these labels, little room is made either for distinctions between discrete societies and polities or for non-Anatolian, nonTurkish, and non-Islamic relationships and continuities.

This is all the more true in the case of art and architectural historiography, where the strain of simplification is coupled with the rigidity of a formalist methodology that has dominated scholarship in Turkey, especially in the latter half of the twentieth century. With its emphasis on morphology and typology, this formalist methodology has defined the limited set of terms with which the architecture of the medieval period has been conceptualized. The workings of a formalist method of inquiry can be readily gleaned from the scores of monographs, typically devoted either to a single building type, such as the madrasa, or to the medieval architectural heritage of a single town or dynasty. While undeniably useful in their capacity as handbooks, these studies nevertheless perpetuate an uncontested and frozen vision of architecture that, except for the establishment of dates and names, is largely divorced from the historical context and is presented in a strictly hierarchical and categorical framework. Although the historical context is not entirely ignored, it is commonly relegated to a discrete introductory chapter and submitted as a separate narrative disconnected from the discussion of buildings. In the 
city and dynasty monographs, the architecture is sorted and studied on the basis of typology and according to a preestablished hierarchy of buildings in which mosques are almost always discussed first, followed by madrasas, tombs, baths, fountains, and domestic architecture. This hierarchical pigeonholing exemplifies the extent to which the formalist methodology predetermines the rationale for and organization of the presentation of buildings. Similarly, monographs dedicated to a single building type are structured according to morphology so that, for example, madrasas with open courtyards are separated from those with closed courtyards. In this approach, building plans have acquired paramount epistemic importance and constitute the primary unit of description and comparison, with a view toward establishing a constructed typology. Formalism in this instance, it could be argued, promotes the pristine two-dimensional plan over the gritty threedimensional building.

Part of the appeal of this formalist methodology for the historiography of medieval architecture in Anatolia no doubt lies in its manageability. With the categories of analysis largely determined prior to the investigation itself, the task of sorting and classifying buildings is automatically achieved and extricated from the irregularities of historical context. Without the challenge of reconciling buildings with their complicated social-political histories, the complexity of architectural practices is simplified and contained along formal lines. Such simplification allows buildings to be easily absorbed into another simplified category-the medieval period defined by the hazy labels of "Seljuk" and "Beylik" - and in turn to be readily identified within a national matrix. Whether qualified with such compound adjectives as "Anatolian-Turkish" or "Turkish-Islamic" or simply identified as "Turkish," the striking of the national keynote replaces the dissonances arising from a complicated historical context. Furthermore, the Turkishness of the architecture is linked, implicitly or explicitly, to its formal characteristics, and is inscribed into the idea of a continuous and self-aware Turkish architectural tradition that originates in Central Asia and anticipates final fulfillment under the Ottomans. Condensed to less than the sum of their parts, buildings subjected to a strict formal analysis are fractured to generate a set of forms, or "building blocks," that are envisioned to support a geographic and chronological continuum of national architecture. ${ }^{1}$

The establishment of a particular formalist meth- odology of art and architectural history in twentiethcentury Turkish academia has a number of intellectual undercurrents. Among the most influential of these is a movement generated within the Vienna School of Art History, to which should be attributed the missionary incorporation of "Turkish art" as a subfield in a universal art history. This essay seeks to investigate the ideological and methodological principles that formed the academic conceptualization of Turkish Art (a conceptualization designated throughout this article by capitalization of the $a$ in "art") by the Viennese scholars Josef Strzygowski, Heinrich Glück, and Ernst Diez and the direct contributions of these scholars to the teaching of the subject in the universities of Istanbul (Faculty of Literature) and Ankara (Faculty of Language, History, and Geography). The causality of formalism and its ideological extensions are, of course, limited neither to these individuals, who established an art-historical umbilical cord between Austria and Turkey, nor to the particular university departments and faculties in which their legacy was sustained. A thorough undertaking of the study of Turkish Art in twentieth-century Turkey cannot ignore the "home-grown" school of formalist art history, led especially by Celâl Esad Arseven in the Academy of Fine Arts in Istanbul, and its influence on the intellectual formation of artists and architects who in turn lent their voices to the academic discourse on the subject. ${ }^{2}$ Equally essential to a more complete picture of the subject is the role played by the French scholar Albert Gabriel, whose remarkable documentation of the medieval architecture of Anatolia continues to serve as a critical cornerstone. ${ }^{3}$ The limited scope of this essay, therefore, is envisioned to shed light on one particular aspect of a much larger topic by means of a case study on the workings of a methodologically driven vision of Turkish Art in the first half of the twentieth century.

\section{OUT OF VIENNA: STRZYGOWSKI'S FORMALISM AND THE CASE FOR TURKISH ART}

The entrenchment of formalism in modern Turkish architectural historiography and its explicit or implicit intertwinement with nationalist sentiment can be traced back to the establishment of Turkish Art as a rightful field of art-historical investigation in the early decades of the twentieth century. The earliest publication to sport such a title was the essay Türkische Kunst, by the Austrian art historian Hein- 
rich Glück (1889-1930), issued in 1917 to inaugurate the founding of the Hungarian Institute in Istanbul. ${ }^{4}$ Glück's explicit aim was to endorse the very notion of a Turkish Art as the sign of a national and racial spirit extending from what were taken to be the earliest traces of Turkic material culture across the Eurasian lands to the major works of classical Ottoman art and architecture-to answer in the positive the raw question, "Gibt es denn eine türkische Kunst?" (Is there indeed a Turkish Art?). ${ }^{5}$ The point of departure in this dramatic journey (accomplished, needless to say, by means of extreme abridgement) was the ornamental character of metal and textile arts, which were held to be innate to the artistic production of nomadic peoples such as the Turks. Accordingly, Glück maintained that the Turks, as they migrated to the central Islamic lands, brought their "racial characteristic" (Rasseneigenart $)^{6}$ to ninth-century Abbasid Samarra and Tulunid Cairo, where it materialized in the decorative character of stucco wall revetments. In subsequent centuries, Glück furthermore contended, the integrity of the Turkish artistic heritage manifested itself in an inclination toward architectural monumentality embodied by forms such as domes and portals, which may have been borrowed from other traditions but were combined and disseminated according to a Turkish national spirit. This proposition was illustrated by examples from Mamluk Egypt, Seljuk Anatolia, Timurid Central Asia, and the Ottoman capitals. Nevertheless, since the formal essence of Turkish Art was seen to inhere most fundamentally in metalwork and textile arts, Glück closed his essay by crediting the flowering of these two media in the Islamic lands to the arrival of Turks. Written against the backdrop of the First World War, to which Glück dolefully alluded at the end, this essay formed the first stand-alone narrative of Turkish Art as a sovereign and significant participant in a universal history of art. The simplification of its framework of inquiry-untroubled by the historical complexities and variables surrounding the movement of Turkic peoples from Asia to Constantinople and beyond-carried the hallmarks of a case made for a national art along formalist lines.

Glück's mission to uphold Turkish Art as a necessary and discrete field of art-historical research was born directly out of an academic movement in Vienna spearheaded by his mentor, Josef Strzygowski (18621941), who made a seminally controversial career out of rallying against the Rome-centrism of art-historical discourse in the European academies. Appointed to a chair in the prestigious Institut für Kunstgeschichte at the University of Vienna in 1909, Strzygowski, an enormously prolific author, exerted his professional influence to assert that the essential foundations of late antique and medieval European art extended beyond the Mediterranean basin to the Eurasian landmass. With the publication of Orient oder Rom: Beiträge zur Geschichte der spätantiken and frühchristlichen Kunst (Orient or Rome: Contributions to the History of Late Antique and Early Christian Art) in 1901, Strzygowski took aim at what he perceived, not entirely incorrectly, to be a biased and exclusivist account of late antique art that limited itself to a narrow conceptualization of the Greco-Roman tradition. ${ }^{7}$ He championed instead the critical testament of the "Orient" (extending eastward from Anatolia and Egypt) in the foundations of early Christian and medieval European art and, in doing so, sought to undermine the classical bias of the humanistic disciplines. His anticlassical perspective persuaded him of the importance of expanding the geography of art history beyond Europe to encompass much of Asia, a task to which he devoted himself with remarkable zeal. His apparent readiness to sacrifice depth for the sake of breadth was the product as much of his personal intellectual ambitions as it was of a particular combination of methodology and ideology, the impact of which can still be felt today. ${ }^{8}$

Subscribing to a strictly formalistic art history concerned primarily with morphological continuities and transformations assessed in a comparative framework, Strzygowski harbored, furthermore, a deep-seated suspicion of the relevance of texts and contexts. Seeking to displace by artifact and ornament what he perceived to be the domination of the text, he remained indifferent and even hostile to the idea of admitting historical context into what he frequently termed vergleichende Kunstforschung (comparative art research) or vergleichende Kunstwissenschaft (comparative art science) as opposed to the traditional Kunstgeschichte (art history). He declared that “...Archaeology must give up its false methods, the philological and historical, based on texts or the chance survival of individual monuments, and the philosophical and aesthetic, which evade the fact of evolution. The history of art must...concentrate upon the work of art and its values, absolute and evolutional, and so find a path of its own." ${ }^{9}$ The path that Strzygowski chose to forge in art history was guided by his uncompromising adherence to these methodological principles, which he continuously emphasized even as he sought to dem- 
onstrate the critical importance of Oriental art for understanding the origins and character of Western art. In doing so, he ventured into vast tracts of Asian art then outside of the purview of European scholarship. In this regard, Strzygowski is rightfully credited with effectively challenging the Eurocentric vision of art historians in the early twentieth century. However, his radical geographic expansion of the field of arthistorical research also served an ideological agenda: to advocate the artistic and cultural primacy of Northern or Aryan peoples, which he aimed to illuminate from the vantage point of the East. Not surprisingly, in the years leading up to and including the Second World War, Strzygowski's ideological rhetoric assumed an increasingly racist tone, pitched to proclaim the superiority of an Aryan artistic legacy. ${ }^{10}$

In 1917, the same year as Glück's inaugural essay on Turkish Art appeared in print, Strzygowski published Altai-Iran und Völkerwanderung: Ziergeschichtliche Untersuchengen über den Eintritt der Wander- und Nordvölker in die Treibhäuser geistigen Lebens (Altai-Iran and the Migration of Nations: Ornament-Historical Investigations on the Entrance of Migrating and Northern Nations into the Hothouses of Spiritual Life). ${ }^{11}$ The central mission of this book was to bolster Strzygowski's expanded geography of art by substantiating the creative energies of a Northern or Aryan art through the evidence of the southward movement of nomadic peoples from the northern regions of Inner Asia. The title reference to Altai and Iran designates, respectively, the upper and lower limits of a middle region that Strzygowski loosely defined between the geographic (and cultural) polarities of North and South. ${ }^{12}$ Positing the phenomenon of Völkerwanderung as the primary mechanism of artistic dissemination from North to South, Altai-Iran assigned the pivotal role of transmitter to two nomadic "races"- the ancient Turks (Alttürker) of the "Altaic sphere" and the Scythians of the "Aryan sphere"-who negotiated this middle region. For the most part the book steered clear of historical contextualization as Strzygowski-untrained in the relevant languages, apparently indifferent to historical details, and inevitably unfamiliar with the more remote regions in question-engineered a grand narrative of artifact and ornament. He undertook the task of demonstrating the evolution of ornamental forms that he envisioned to have migrated from a nebulous North across vast tracts of land, under the aegis of nomadic peoples such as Turks and, before them, Scythians, who effected their entrance into the cultures of the South (especially Mesopotamia and Egypt), the "Hothouses of Spiritual Life." This loaded subtitle to AltaiIran has an unmistakable biological tinge, the concept of Treibhäuser (hothouses or greenhouses) signifying the germination of forms from the creative North implanted in the lands of the fertile South.

Strzygowski conceived of his foray into "ancient Turkish art" (alttürkische Kunst) as breaking new ground in research and asserted that art history could no longer make do without it. ${ }^{13}$ The section of Altai-Iran titled "Die Türkvölker und der altaische Kreis" (Turkic Peoples and the Altaic Sphere) begins with sweeping statements and ponderous questions about the artistic culture of nomadic Turks. ${ }^{14}$ Without any obvious concern for chronology, Strzygowski launched his account of this ill-defined subject with a discussion of textile arts (illustrated by instances of carpets depicted in Buddhist wall paintings) and metalwork (focusing on the famously enigmatic Nagyszentmiklós Hoard, discovered in Romania in 1799, which included objects with Turkic runic inscriptions). These he singled out as media native to nomadic Turks prior to their absorption by the sedentary cultures of Islam in the Near East. The section then proceeded to introduce various ornamental motifs of surface decoration, culminating in an analysis of the stucco decoration of the ninth-century mosque of Ibn Tulun in Cairo, which Strzygowski upheld as an integral example of Turkic nomadic ornamental art transplanted to Egypt. In the concluding chapter to Altai-Iran, Strzygowski returned to the subject of the role of Turks in the grand NorthSouth dialogue and asserted that Turks exerted their distinctive influence on the "evolution of art" (Kunstentwicklung) so long as they "remained true" to their nomadic nature, which he identified geographically with their "pasture lands and hunting grounds." 15 Interpreting the stucco decoration of Tulunid Cairo and Abbasid Samarra as the unadulterated expression of nomadic ornament, Strzygowski proclaimed Seljuk and Ottoman art to represent a later stage, in which the nomadic essence of Turks had already been assimilated by the Treibhäuser of the South, so that Seljuks and Ottomans essentially became "carriers" (Träger) of Islamic art forms they had picked up in Iran and Syria.

The arbitrary nature and unsubstantiated identification of the selection of works used to illustrate these topics indicates Strzygowski's inevitably patchy grasp of 
the material in this enormous territory, which, in 1917, remained largely uncharted. However, working with predetermined categories of medium and ornament type, Strzygowski's formalistic methodology allowed him to circumvent the thorny questions of historical connection and cultural relevance. In this framework, almost no painting, object, or building was considered in its entirety; instead, Strzygowski extracted ornamental motifs or compositional elements to provide a distilled vision of forms that he manipulated as signposts on the migratory path of the nomadic Turks between Inner Asia and Egypt. Thus, for example, he extracted Ibn Tulun's stucco decoration from its architectural framework and provided only schematic drawings of the designs. The logic of Strzygowski's approach was summarized by Ernst Diez (1878-1961) in a partially critical assessment of his former teacher's legacy:

For a comparative investigation, a wide and profound knowledge of detail in the different areas of Asiatic art was not necessary, because here the important thing was mainly the comparison of types and the identification of formal similarities or dissimilarities. The comparative science of art (vergleichende Kunstwissenschaft) alone could show what kind of artistic archetypes humankind produced, what was the ultimate signification of these creations, and which untransgressable borders were put in front of the various human collectivities. ${ }^{16}$

Ignoring the sum total of any given work of art in its proper historical and geographic context, Strzygowski instead constructed a paradigm of nomadic art by associating individual parts fragmented and isolated from otherwise discrete and complete works according to a preconceived notion of artistic transfer from North to South.

This strategy of sacrificing the whole for the parts goes to the heart of Strzygowski's intertwinement of ideology and methodology. Although the grand aims and scope of his studies fabricated a facade of vast proportions, closer consideration reveals a reductive conceptualization that permeated and guided his thought. Behind Strzygowski's inclination toward the geographic expansion of art-historical investigation is a simplistic configuration of cardinal points that he deployed to signify eternal disparity and opposition. Thus, the North stood for the Aryan homeland and the South comprised the Treibhäuser of China, India, and the Near East. The tensions and contrasts between North and South are played out in the East (the heartlands of Asia) and the West (Europe). The rhetorical weight of these primary ordinates can be felt throughout Strzygowski's scholarship-most notably in the title of Altai-Iran - where they clearly served to ingrain a geographically and ideologically polarized view of regions, cultures, and, ultimately, humanity. This polarizing strategy of epistemic simplification remained a guiding principle in his formalistic methodology, which he systemized and advocated with great perseverance. Strzygowski's preferred designation for his methodology, vergleichende Kunstforschung, is sufficient to express both his emphasis on comparison as the primary tool of analysis and his conspicuous ignoring of contextual investigation, indicated by the substitution of the ahistorical concept Kunstforschung for the traditional Kunstgeschichte.

In 1922, Strzygowski published Kunde, Wesen, Entwicklung, for which he wrote a lengthy introduction, outlining the particulars of his methodology. ${ }^{17}$ Here he distilled his brand of Forschung (i.e., Kunstforschung) and contrasted it with "historical thinking" (geschichtliche Denken), which he declared to be bound by time. He advocated research unhindered by historical thinking so as to allow the essence (Wesen) of things to be recognized "within the framework of comparative observation based on scientific parameters (Fachwerte)." In this way, he contended, research would "enter into close connection with the present and inject new life into the petrifications of history." He condemned the historical-philological approach of most scholars for their reliance on a deductive methodology, as opposed to the inductive methodology that he upheld. ${ }^{18}$ Strzygowski's introduction was followed by essays on various topics of non-Western art, written by his studentsamong whom were Glück and Diez-and intended to demonstrate the application of this inductive methodology. The title of the book, Kunde, Wesen, Entwicklung, provides the thematic order that Strzygowski promoted as the organizing principle of analysis and writing. Accordingly, Kunde comprised the introduction of the artworks and their basic identifiers: artist, provenance, and period. This was seen as groundwork for the more critical analysis of Wesen (essence or nature) and Entwicklung (evolution or development). Under the concept Wesen, Strzygowski distinguished the formal qualities of artworks that are intrinsic and thus constitute their "essence." The analysis of Wesen consisted of five parts in ascending order of significance: Rohstoff und Werk (raw material and craft), Gegenstand (subject), Gestalt (shape), Form (form, or the synthesis of Gestalt), and Inhalt (content). The identification of 
Wesen was conceived as the basis for understanding the process of "evolution" (Entwicklung), by which Strzygowski meant the global movement and transformation of art forms. Entwicklung, the ultimate objective of Kunstforschung, comprised three sequential parts: Beharrung (persistence or origination), Wille (intention or force), and Bewegung (movement or dissemination).

Strzygowski's commitment to a blatantly ahistorical and severely formalistic methodology provided the theoretical and systemic license by which he dissolved artworks in an attempt to detect their "essence" and subsequently recomposed them into a narrative of "evolution" with global signification. Not unlike the geostrategic formula of "divide and conquer," Strzygowski's methodology clearly developed in tandem with his ideology. Anticlassical, anti-imperial, and antihumanistic, this ideology was enabled to a large degree by detaching art from its historical context and constructing a vision of culture that was fragmented and reconstituted in order to serve the narrow and divisive objectives of nationalism and racism. His privileging of the idea of "evolution" served to lend credence to the notion of Aryan art, which he had already asserted in Altai-Iran by foregrounding the fact of nomadic movement and tracing the "essence" of nomads' ornament from North to South. The highlighting of Turkic and Scythian art in this endeavor thus provided a convenient channel of dissemination from a nebulously remote North to a familiar South, in order to redress what Strzygowski perceived to be a disparity in the relative importance accorded to these polarities. Strzygowski pronounced his ideological agenda for Altai-Iran to be the continuation of the struggle (Kampf) he had begun with two previous worksOrient oder Rom and "Hellas in des Orients Umarmung" (Hellas in the Embrace of the Orient) ${ }^{19}$ which he hoped would ultimately support Germans' stake in the global arena of culture by initiating research into Indo-Germanic art. ${ }^{20}$ It must be said that such high-flying projections were hardly exceptional within early-twentieth-century Austro-German art history, which was generally permeated with considerations that linked art to the characteristics of place and people described in absolute and essentialist terms. ${ }^{21}$

\section{INTO ISTANBUL AND ANKARA: THE PRESENTATION OF STRZYGOWSKI'S METHODOLOGY IN TURKEY}

Notwithstanding its ultimate aim to promote Germanic and Aryan accomplishments in the sphere of art, Strzygowski's affirmation and manipulation of alttürkische Kunst as a valid and necessary category of Kunstforschung extended beyond the pages of Altai-Iran to influence the development in Turkey of twentieth-century discourse on Turkish Art. Strzygowski's emphasis on and justification for essentializing the art of discrete Völker (nations or peoples), and his affirmation of the very existence of a Turkish Art, naturally resonated in Turkey after the establishment of the Republic in 1923. Invited to contribute to the third volume of the newly launched journal, Türkiyât Mecmuası, published by the Turcology Institute of Istanbul University, Strzygowski returned in 1926-27 to the subject he had first launched in Altai-Iran. His article, translated into Turkish and titled "Türkler ve Orta Asya San'atı Meselesi" (Turks and the Question of Central Asian Art), is a drawn-out and amplified version of the ideas he had put forth in Altai-Iran, with an explicit nod to the early Republican audience of Türkiyât Mecmuası. ${ }^{22}$ Having systemized his methodology since the publication of Altai-Iran in 1917, he now presented his ideas on Turkish Art within the strict framework of Kunde, Wesen (and its five subcategories), and Entwicklung. Accordingly, and as the title of the article implies, his perspective privileged the notion of origination and movement to promote the idea of an essential Turkish character in the arts that he attributed to Turks. The stated objective of the article was to demonstrate ultimately the connection of "Turkishness" with Central Asia. ${ }^{23}$ Strzygowski expressed his disagreement with the view that Turkish Art began only with the Seljuks and came into being solely with the contribution of non-Turkic peoples. He contended that the "origin of Turkish art-where the characteristics constituting its actual strength are most apparent-extends to a distant past, and that the actual essence of Turkish Art was unchanged by Iran, Iraq, Syria, Egypt, Asia Minor, or Byzantium."24

Strzygowski began the section on Kunde (Abideler) with artworks of the Ottomans and continued backwards in time to introduce those of the Seljuks (comprising the Great Seljuks and their successors), the Tulunids, and the Turkic peoples of Inner Asia. ${ }^{25}$ These he categorized as "Turkish monuments docu- 
mented with inscriptions." He then proceeded to discuss "Turkish monuments not documented with inscriptions," under which category he included artworks of the Huns and the Avars, finally arriving at the "great gaps" (büyük bosluklar), by which he meant "the plains of upper Asia and southern Siberia," the homeland of the Turks, where "no artwork accepted as belonging to the Turks has been found." ${ }^{26}$ For filling these gaps he offered the evidence of the familiar twosome of textile and metal arts:

In order to investigate the artworks of Turks in their homeland, we do not attach much importance to stone or brick architecture; rather, we consider important the raw materials they worked while they were a shepherding people, that is, the wool they obtained from their animals and the metals they encountered in the mountains they inhabited. ${ }^{27}$

These ideas follow directly from Altai-Iran. For the appreciation of the "essence" of Seljuk and Ottoman art, however, Strzygowski now adopted a more equivocal position than the one he had defended in Altai-Iran. Instead of dismissing the Seljuks and Ottomans as merely the "carriers" (Träger) of art forms picked up in Iran and Syria, he now conceded that "the Turks were the agents of certain art forms they brought from the East." 28 This seemingly softer stance speaks to the difference in the ideological slants of Altai-Iran and this article: while the former sought to distinguish categorically between the cultures of the North and the South and made use of ancient Turkish Art mainly to validate this distinction, Strzygowski must have recognized that giving such short shrift to medieval and later Turkish Art would not have gone down well with the particular audience of the article in Türkiyât Mecmuası. Even less palatable would have been the viewpoint he had expressed in 1902, in "Hellas in des Orients Umarmung," about the "rape of Greek art by Turks." 29 Thus he tempered his rhetoric somewhat for Türkiyât Mecmuasi; yet, while appearing to maintain the notion of an art that is essentially and enduringly Turkish, he also left the door open to the idea of possible influences from non-Turkic cultures as part and parcel of his perennial position regarding the force exerted on the North by the South. This rendered his discussion of the methodologically predetermined theme of the Entwicklung of Turkish Art especially woolly, inasmuch as he attempted to reconcile the categorical issue of origination (comprising such essentializing rubrics as climate, soil, and race $)^{30}$ with that of movement, in which the ideas of encounter and influence were central.

This kind of intermittent confusion meant that Strzygowski's article in Türkiyât Mecmuası gathered its momentum not from evidence-based argumentation and substantiation of his position but rather from recurrent invectives against the Eurocentric art-historical establishment (the "humanists," whom he never missed an opportunity to oppose) for ignoring the testimony of textile and metal arts, combined with a fervent call for an ingathering of these materials by Turkish scholars in order to prove the very existence of a discrete Turkish Art with essential characteristics. He recommended the establishment of a "Turkish national museum," preferably in Ankara, where it would be "under the political authority of Turks." In order to define a central field of authenticated Turkish Art, this national museum would collect and have sole jurisdiction over not just Seljuk and Ottoman works but especially examples of tent and metal arts from the original homeland of the Turks in Inner Asia. Any other art forms would be judged on the basis of their relation to Turkish Art and accordingly categorized in appropriate sections. This idea was formulated not only to address the presumed cultural desiderata of the young Turkish Republic but also to bolster Strzygowski's denouncement of the collecting and exhibiting policies of European museums. Indeed, he envisioned the Turkish national museum as a force to counter Europe. ${ }^{31}$

Such a museum was never founded in Ankara; the Hittite Museum (later renamed the Museum of Anatolian Civilizations), established in 1938, highlighted the Anatolian rather than the Central Asian identity of the new nation-state. Within the realm of state museums at least, the cultural politics of the Turkish Republic ultimately steered past this particular vision of Strzygowski's to focus overwhelmingly on the consolidation of Anatolian archaeology, marginalizing medieval and later periods as "ethnographic" material. Nevertheless, thanks to its publication in Turkish, the article in Türkiyât Mecmuası made Strzygowski's ideas eminently accessible in Turkey and lent a voice of authority to the academic expansion of the field of Turkish Art there. ${ }^{32}$

Indeed, Turkish Art as a field continued to be shaped in great measure by students of Strzygowski who were appointed to teaching positions in Istanbul and Ankara in the 1940s and 1950s; the profound influence of their former teacher is evinced by such 
publications as Kunde, Wesen, Entwicklung, in which his methodology is adopted to the letter.

Of all these students, it was Heinrich Glück who shadowed his teacher most closely: the correspondence between Glück's 1917 essay on Turkish Art and Strzygowski's discourse on the topic in Altai-Iran, published the same year, shows the degree to which Glück espoused Strzygowski's framework of analysis, especially with regard to the assumption of an essential Turkish artistic spirit exemplified in textile and metal arts. The joint reproduction of certain images as illustration of these themes undoubtedly indicates extensive collaboration between the two scholars, although this is not specifically acknowledged by either party. Glück's faithful adherence to Strzygowski's ideas was nevertheless highlighted by Diez, who pointed out the pressure exerted on Glück to reproduce his mentor's viewpoints while they were both teaching in the same institution. ${ }^{33}$

That Strzygowski and Glück were mutually and similarly invested in the subject of Turkish Art in the 1920s is also suggested by the Glück's contribution to the same volume of Türkiyât Mecmuası for which Strzygowski had written. Titled "Türk San'atının Dünyadaki Mevkii" (The Status of Turkish Art in the World), Glück's article underlined the global status of Turkish Art and chastised European art historians for their introverted account of a linear and self-contained artistic development from ancient Greece to contemporary Europe. ${ }^{34}$ Glück's arguments here accentuate and even exceed Strzygowski's position on the notion of Turkish Art with its own inherent characteristics; without leaving any room for ambiguity, they make a more assertive and portentous case for the continued existence of an autonomous national art evinced by the dissemination of certain forms. Unlike Strzygowski, Glück expressed no reservations about bringing Seljuk and Ottoman art wholesale into the fold of this national art. He not only rejected outright the possibility of significant influence from non-Turkish elements on Seljuk and Ottoman art but, seeking substantiation from the depths of history, also looked favorably upon the "new viewpoints" that suggested racial associations between the ancient Turks and the ancient cultures of the Hittites, Sumerians, and others. These might, it seemed to Glück, explain why Turkish Art eventually presented so many connections to non-Turkish traditions of the Near East and the Mediterranean: the global impact of the movement of Turks in the medieval and early modern periods, and the cultural-artistic manifesta- tions of this movement, could be explained with reference to ancient parallels. Glück concluded that the various state formations of the Turks throughout history lent credence to the "new viewpoints" and supported the claim for a sovereign and superior Turkish Art of world status:

The arts that the Turks created with these empires have always been generated from the permanently national soil and have absolutely not been born of foreign elements. The Turks have made use of foreign elements only to derive nourishment for the ennoblement of their national art. ${ }^{35}$

Disallowing the phenomenon of eclecticism to explain the character of Turkish art, Glück furthermore contended, "The development of the great Turkish art is the product of a great racial unity that molded foreign factors with its own spirit." ${ }^{36}$

Glück's conceptualization of Turkish Art in this article followed the ideological direction established by Strzygowski but did not harbor the same hesitation about the Turkishness of Seljuk and Ottoman art. However, Glück's rhetoric, built on the ideologically compliant methodology of Strzygowski, was not always set to a steady pitch. Just a few years earlier, in 1923 (the same year he was promoted to the rank of professor in Vienna), he had published in Leipzig a booklet titled Die Kunst der Seldschuken in Kleinasien und Armenien (The Art of the Seljuks in Asia Minor and Armenia), which presented a more flexible assessment of the character of Turkish Art. ${ }^{37}$ Here Glück more readily acknowledged the diverse sources and agents of Seljuk architecture-an observation he nearly refused to allow himself in the article in Türkiyât Mecmuası-and defined Turkish Art largely in terms of its acquisition of "foreign elements" that it infused with a national spirit arising from the innate national strength (volkliche Eigenkraft) of the conquerors. ${ }^{38}$ Glück's different inflection of the essence of Turkish Art in these two publications may perhaps be explained as an adjustment born of his own anticipation of the different expectations and dispositions of the two audiences, one in Weimar Germany, the other in early republican Turkey. As such, this adjustment recalls Strzygowski's more nuanced discussion of Seljuk and Ottoman art in Türkiyât Mecmuası as compared to his glib dismissal of the topic in Altai-Iran. This kind of adjustment of ideological focus in the definition of "Turkish" clearly rested on the application of Strzygowski's methodology, which was uncompromising in its essen- 
tialism of form, indifferent to contextual interpretation, and, as a consequence, liberal in its audiencetargeted subjectivity.

It is easy to imagine that Glück, had he not passed away in 1930 at the age of only forty, would have been the natural choice to carry Strzygowski's torch formally into Turkish universities. That task fell instead to Ernst Diez, who in 1943 was appointed to chair the new art history department at Istanbul University, and to Katharina Otto-Dorn (1908-99), who undertook the same responsibility at Ankara University in $1954 .{ }^{39}$ While Diez and Otto-Dorn both stayed only briefly in their respective positions, they nevertheless set the course for the subsequent teaching of Turkish Art in Turkey. In Istanbul, Diez worked with his young Turkish assistant, Oktay Aslanapa (b. 1914), who had obtained his doctorate in art history from the University of Vienna in 1943 under Diez's own direction. Otto-Dorn and Diez-the latter soon followed by Aslanapa-broadly introduced to Turkish academia the methodological tradition of formalism that Strzygowski had rigorously enforced in Vienna. Although none of these scholars wholly replicated Strzygowski's conceptualization of art history, they remained largely within the formalistic parameters of the methodology that constituted their training. ${ }^{40}$

Nevertheless, Diez's relationship to the scholarship of his teacher was not one of unquestioning assent. Diez and Strzygowski had held different opinions on the dating of the famously controversial Mshatta facade, about which discussion raged in the first decade of the twentieth century. Even in 1910, after Ernst Herzfeld had convincingly argued the case for an Umayyad dating, Strzygowski, true to his inflexible character, continued to insist on a pre-Islamic, fourth-to-sixth-century Sasanian dating, with which Diez remained in apparently awkward disagreement. Diez later voiced some of his reservations about his former mentor in an obituary of Strzygowski, which was published in both Turkish and German in the journal Felsefe Arkivi, issued by the department of philosophy at Istanbul University. ${ }^{41}$ In this obituary, Diez criticized Strzygowski for his intractable position on Mshatta and for "going too far" in his later years in his blind insistence on the importance of the North. Without explicitly addressing the issue of race that had so permeated Strzygowski's writings, Diez referred to his "romantic views and imaginary findings," which nevertheless "did not lessen the great services he rendered" in his long career ${ }^{42}$-services that included Strzygowski's geographic expansion of art history and the successful challenge he posed to the prevailing Eurocentric perspective of the discipline. Diez also explained that this expansion formed the backbone of Strzygowski's comparative methodology, which he outlined in a generally favorable light, praising its systematic conceptualization and positive influence on the work of the numerous art historians who adopted it.

Diez revisited Strzygowski's legacy in 1960, in a posthumously published essay mainly critiquing his mentor's ideas about Iranian art. ${ }^{43}$ Although in this instance Diez was more blunt about the aggressive and inflexible disposition that characterized Strzygowski's professional life, he nevertheless stood by the logic of vergleichende Kunstwissenschaft and its allowance for intuitive analysis. ${ }^{44}$ Thus, while the paths of the two scholars clearly diverged in a number of instances, Diez generally accepted the formalistic methodology instituted by the Strzygowski as objective and useful for charting the new territories of art history.

Diez's tenure in Istanbul between 1943 and 1948 was relatively brief and further shortened by his internment in Kırşehir in 1944-45, following Turkey's eleventhhour declaration of war against Germany. Despite these wartime difficulties, he left one important token of his time in Turkey, in the form of a textbook on Turkish Art. Translated into Turkish by Aslanapa, Türk Sanatı was issued in 1946 as the inaugural publication of the new history of art department of Istanbul University's Faculty of Letters. ${ }^{45}$ It was subtitled Basslangicindan Günümüze Kadar (From the Beginning to the Present) and accordingly began with the earliest historical mentions of Turkic peoples, from seventh-century Chinese sources. This was followed by an elaboration of "the boundaries of the term Turkish art," in which Diez explained that Turkish Art can be divided into two-a folk art of the nomadic peoples and an art of the urban and sedentary "Turkish-Islamic state"-and that these branches coexisted but had no real rapport with each other. ${ }^{46}$ After mentioning, à la Strzygowski, that the character of nomadic folk art could be gauged from textile and metal arts, Diez launched an extensive discussion of the latter category under the subheading "Evrazya Hayvan ve Filiz-kıvrım üslûbu" (Eurasian Animal and Vegetal-Scroll Style). ${ }^{47}$ Here he referred extensively to the work of the Russian scholar Mikhail Rostovtzeff who, in 1929, had published a widely disseminated study of Scythian metalwork in which he coined the term "Eurasian animal style." 48 Adopting the perspective that the nomadic Turks also partici- 
pated in the development and dissemination of this style, which is commonly attributed to the Scythians and Sarmatians, Diez proposed that some of the figures in the remarkable Scythian gold plaques discussed by Rostovtzeff exhibited Turkic physiognomies. ${ }^{49}$ His elaboration of the subject of decorative styles reveals an essentialist and categorical outlook that associated certain formal characteristics of surface decoration with geographic-cultural inclinations. He held that nomadic cultures such as the Turkish clans of Asia preferred dynamic and open forms, while sedentary cultures favored static and closed forms. ${ }^{50}$

Türk Sanatı exhibits some notable divergences from Strzygowski and Glück's conceptualization of Turkish Art, insofar as Diez largely steered clear of an explicitly race-conscious rhetoric and such notional pronouncements as the manifestation of a "Turkish spirit" in the arts. Rather, the raw ideology of Strzygowski and Glück appears to have been digested and the essentialist interpretation of forms taken for granted. The book is still governed by a formalistic methodology that becomes particularly apparent in the sections on the architecture of the Seljuks and the Ottomans. Beginning with a morphological breakdown of architectural elements (support systems, column capitals, arches, fenestration, superstructures, portals, and mihrabs), ${ }^{51}$ Diez continues with a chronological and typological presentation of Seljuk and Ottoman architecture before concluding with sections on sculpture, ceramics, painting, and calligraphy. In the sections on Seljuk architecture, he makes repeated mention of the employment of craftsmen of various backgrounds, painting a multicultural picture of the artistic scene in medieval Anatolia. He cites the appropriation of indigenous styles and techniques in Anatolia as the basis of the character of Turkish-Islamic art, which he declares to be entirely distinct from the nomadic folk arts exemplified by textiles and metalwork. However, his discussion of tomb architecture and portal decoration under the Seljuks occasionally qualifies this claim. Singling out the remarkable decorative monumentality of Seljuk portals, he likens their surface patterns to carpet decoration and suggests that the "centuries-old textile arts of Central Asian nomads have here risen to [the level of] a monumental art. ${ }^{52} \mathrm{He}$ then supposes a probable kinship between the design of these portals and "entrances to ancient tents or nomadic palaces." ${ }^{33}$ Although a good portion of the book comprises a descriptive account of Turkish art, such speculations illustrate Diez's taste for intuitive reasoning within the formalistic parameters of Strzygowski, who similarly defended an inductive rather than a deductive interpretation of forms.

Diez left Istanbul University in 1948 but returned to Turkey one last time in 1959, on the occasion of the First International Congress of Turkish Art, held in Ankara. In many ways, the launching of this congress (which is organized every four years in a different city) marked the culmination of the objectives that Strzygowski and his students held for Turkish Art. The keynote address of the congress was delivered by Suut Kemal Yetkin (1903-80), the rector of Ankara University and a scholar of aesthetics and literature. Yetkin's opening words underline an awareness of the former disparagement of Turkish Art and convey an appreciation for the recent shift in art-historical discourse:

Until recently, Turkish art had been treated with much injustice; it was automatically believed that this art did not go beyond the boundaries of imitation, that it was devoid of all originality, that the Turks, brave soldiers, were always lacking in artistic capacity...At the time when foreign books and articles discussing our art in this cavalier manner were being published, we did not yet have institutes dedicated to Turkish art; the number of people working on the subject was much more limited than today; the responses of our writers to these attacks did not pass beyond the borders of our country. Yet there were a few friends of Turkish art in the West, such as Strzygowski and Glück, who, through their writings, tried hard to defend it. ${ }^{54}$

By the time the First International Congress of Turkish Art was inaugurated, Strzygowski's mission to uphold the existence of a Turkish Art had been largely accomplished. Divested of its former racist objectives and its rhetoric accentuating Aryan accomplishments (which obviously did not serve the purposes of mid-twentiethcentury Turkish nationalist sentiment), Strzygowski's methodology was instead transformed into a tool for delineating a national art and architecture that extended from the nomadic movements of ancient Turks in the steppes of Inner Asia to their settlement of medieval Anatolia. It was the adoption of the morphological and typological overdrive of Strzygowski's methodology that directed the energies of the first generation of Turkish art historians and set the course for an increasingly introverted and constricted representation of medieval architecture that confined itself to the borders of modern Turkey. However-and almost 
paradoxically—as formalism dominated the approach to the study of art and architecture in twentieth-century Turkey, the idea of a global and all-inclusive Turkish Art came to permeate the thinking about and the teaching of the subject. The textbook Türk Sanatı, produced by Diez during the strenuous war years, proved in the long run to be a well-rooted sapling that, under Aslanapa's regular cultivation, grew to include the art and architecture of all manner of Turkic societies, from India to Egypt. ${ }^{55}$ In the prevailing geographic expansionism of Turkish Art that followed the model of dissemination propagated by Strzygowski, medieval Anatolia-and especially its architecture-was treated as a strait through which a catalogue of forms and types entered a new geography and fused with it, yielding buildings and styles bracketed between an origin in the East and a culmination in Ottoman architecture-that is, buildings and styles asserted as a link in a long chain of national artistic expression. In providing the grammar of a grand narrative of Turkish art, this brand of formalism guaranteed for more than half a century the academic contraction of a complex architectural legacy and the concealment of its manifold horizons.

Department of Archaeology and History of Art Bilkent University, Ankara

\section{NOTES}

1. These general remarks about the adoption and implication of a formalist methodology are borne out by any number of articles or monographs. Crystallization of this methodology may be seen, for example, in one of the more accessible introductions to the architecture of the Beylik period: Olus Arık, "Turkish Architecture in Asia Minor in the Period of the Turkish Emirates," in The Art and Architecture of Turkey, ed. Ekrem Akurgal (Oxford, 1980), 111-36. Here, the indifference to contextual investigation is stated in the introduction (112): "...The architectural works of the period of the emirates [i.e., beyliks] can be studied without distinguishing among the emirates, by classifying the works according to their building techniques and by investigating typology and regional distribution. This is the most logical approach to the architecture of the period of the emirates." This statement is followed by three unequal sections based on building type: mosques, madrasas, and tombs. The section on mosques is further divided into seven subsections, each of which represents a certain morphological category, distinguished by the type of groundplan and domical superstructure. This simplified presentation of the architectural landscape relies on a set of formal common denominators, which are amplified to drown out the cacophony of a complicated historical con- text and replace it with a nationalist keynote. The double emphasis on the adjective "Turkish" in the title of the essay preempts any ambiguity regarding the national identity of the subject matter and its assumed extension from Central Asia to Anatolia. Thus, the subsection "Single-Domed Cubic Mosques" begins with the observation that "this traditional type of building...was especially used in the türbes (mausolea) of Central Asia and Iran-cradle of pre-Anatolian Turkish culture..."(112). The article concludes with the remark,"All the architectural experiments of the period of the emirates in Anatolia were crystallized by the Ottomans into several outstanding features" (136).

2. See Gülru Necipoğlu's account in her article "Creation of a National Genius: Sinan and the Historiography of 'Classical' Ottoman Architecture," in this volume.

3. On the work and legacy of Albert Gabriel, see Pierre Pinon et al., Albert Gabriel (1883-1972): Mimar, Arkeolog, Ressam, Gezgin = Albert Gabriel (1883-1972): Architecte, archéologue, artiste, voyageur (Istanbul, 2006).

4. Heinrich Glück, Türkische Kunst, Mitteilungen des Ungarischen Wissenschaftlichen Instituts in Konstantinopel, vol. 1 (Budapest and Istanbul, 1917).

5. Ibid., 3 .

6. Ibid., 7 .

7. Josef Strzygowski, Orient oder Rom: Beiträge zur Geschichte der spätantiken und frühchristlichen Kunst (Leipzig, 1901).

8. For Strzygowski's career and complex legacy as well as the tensions with his colleague and academic nemesis in Vienna, Alois Riegl, see Suzanne L. Marchand, "The Rhetoric of Artifacts and the Decline of Classical Humanism: The Case of Josef Strzygowski," History and Theory 33 (1994): 106-30; Margaret Olin, "Art History and Ideology: Alois Riegl and Josef Strzygowski," in Cultural Visions: Essays in the History of Culture, ed. Penny Schine Gold and Benjamin C. Bax (Amsterdam and Atlanta, 2000), 151-70; Jaś Elsner, "The Birth of Late Antiquity: Riegl and Strzygowski in 1901," Art History 25 (2002): 358-79. For an insightful study of the impact of Strzygowski on the historiography of Armenian architecture see Christina Maranci, Medieval Armenian Architecture: Constructions of Race and Nation (Leuven, 2001).

9. Josef Strzygowski, Origins of Christian Church Art, trans. O. M. Dalton et al. (Oxford, 1923), viii-ix.

10. Nevertheless, because of his abiding interest in the various artistic traditions of Asia, which he consistently validated in his scholarship in order to express the global impact of Northern/Aryan art, Strzygowski ultimately fell somewhat short of constructing an unadulterated vision of Aryan art and therefore stood perceptibly out of line with the strict racial conceptions of Nazi ideology: see Olin, "Art History and Ideology," 169.

11. Josef Strzygowski, Altai-Iran und Völkerwanderung: Ziergeschichtliche Untersuchungen über den Eintritt der Wander- und Nordvölker in die Treibhäuser geistigen Lebens (Leipzig, 1917).

12. For the contemporary emphasis, by Strzygowski and others, on geography as a defining factor in artistic formation and evolution see Thomas DaCosta Kaufmann, Toward a Geography of Art (Chicago, 2004), 43-58, 68-73.

13. Strzygowski, Altai-Iran, 153.

14. Ibid., 153-87.

15. Ibid., 299. 
16. Ernst Diez, "Josef Strzygowski-Biografisches -7. März 1862 bis 7. Januar 1941," Felsefe Arkivi 2 (1947): 22. The Turkish translation of this article is on 1-12.

17. Josef Strzygowski, Kunde, Wesen, Entwicklung: Eine Einführung (Vienna, 1922), 5-91.

18. Ibid., 6-7.

19. Josef Strzygowski, "Hellas in des Orients Umarmung," Münchener Allgemeine Zeitung, Beilage (18-19 Feb. 1902): 4041.

20. Strzygowski, Altai-Iran, ix.

21. Kaufmann, Toward a Geography of Art. In 1900, for example, Alois Riegl had used a comparison between ancient Near Eastern and Greek sculpture as a springboard to assert the cultural progressiveness of Indo-Germanic peoples: cited in Christopher S. Wood's introduction to The Vienna School Reader: Politics and Art Historical Method in the 1930s, ed. Christopher S. Wood (New York, 2000), 27.

22. Josef Strzygowski, "Türkler ve Orta Asya San'atı Meselesi," Türkiyât Mecmuası 3 (1926-33): 1-80. On page 4 of the article, Strzygowski states that the information he presents is the result of research conducted in 1926-27. The third volume of Türkiyât Mecmuası was not published until 1935.

23. Ibid., 4 .

24. Ibid., 5 .

25. Ibid., 4-17.

26. Ibid., 12.

27. Ibid., 13.

28. Ibid., 17.

29. As cited in Olin, "Art History and Ideology," 165.

30. Strzygowski, "Türkler ve Orta Asya San'atı Meselesi," 4954.

31. Ibid., 78-79.

32. Thus, for example, Strzygowski and Glück's assertions about Turkish Art received the stamp of approval of the eminent historian Fuad Köprülü in his landmark book Türk Edebiyatında İlk Mutasavvflar (Istanbul, 1918; 5th ed. Ankara, 1984), 19495, n. 14.

33. Diez, "Josef Strzygowski," 17 (Turkish trans., 4).

34. Heinrich Glück, "Türk San'atının Dünyadaki Mevkii," Türkiyât Mecmuası 3 (1926-33): 119-28.

35. Ibid., 127.

36. Ibid

37. Heinrich Glück, Die Kunst der Seldschuken in Kleinasien und Armenien (Leipzig, 1923). In the same handbook series, Bibliothek der Kunstgeschichte, ed. Hans Tietze, Glück had also published the booklet Die Kunst der Osmanen (Leipzig, 1922). These handbooks, offering succinct accounts of various periods of art in an accessible format, must have been widely disseminated beyond the academic circles. 38. Ibid., 4.

39. On Katharina Otto-Dorn see Joachim Gierlichs, "In Memoriam Katharina Otto-Dorn: A Life Dedicated to Turkish Islamic Art and Architecture," in M. Kiel, N. Landman, and H. Theunissen, eds., Proceedings of the 11th International Congress of Turkish Art, Utrecht, The Netherlands, August 23-28, 1999, article no. 21, 1-14, published in Electronic Journal of Oriental Studies 4 (2001): http://www2.let.uu.nl/solis/anpt/EJOS/pdf4/ 21Gierlichs.pdf

40. Aslanapa recognized the contributions of the Vienna school in Türkiye'de Avusturyal Sanat Tarihçileri ve Sanatkârlar = Österreichische Kunsthistoriker und Künstler in der Türkei (Istanbul, 1993). The book provides biographies and in some instances bibliographies of Austrian art historians. Aslanapa's biography of Strzygowski presents the scholar in a generally favorable light, although it expresses slight reservation about the "perhaps excessive" importance Strzygowski attached to Armenian art: 35.

41. Diez, "Josef Strzygowski."

42. Ibid., 21-22, Turkish trans., 9.

43. Ernst Diez, "Zur Kritik Strzygowskis," Kunst des Orients 4 (1963): 98-109.

44. Ibid., 107-9.

45. Ernst Diez, Türk Sanatı: Başlagıcından Günümüze Kadar, trans. Oktay Aslanapa (Istanbul, 1946).

46. Ibid., 5 .

47. Ibid., 7-25.

48. Mikhail Rostovtzeff, The Animal Style in South Russia and China (Princeton, 1929).

49. Diez, Türk Sanatı, 13.

50. Ibid., 25-27.

51. Ibid., 41-60.

52. Ibid., 95 .

53. Ibid., 98.

54. Suut Kemal Yetkin, "Discours d'ouverture du Professeur Ordinarius Suut Kemal Yetkin, Recteur de l'Université d'Ankara et Président du Ier Congrès International des Art Turcs," in First International Congress of Turkish Art (Ankara, 1961), 1.

55. In 1955 Aslanapa rehabilitated Diez's survey of Turkish Art and republished the work, adding corrections and elaborations but maintaining the basic outline of the first book: Oktay Aslanapa and Ernst Diez, Türk Sanatı (Istanbul, 1955). In 1971, Aslanapa produced a new book in English that covered more ground: Oktay Aslanapa, Turkish Art and Architecture (London, 1971). This in turn was published in Turkish with some additions and changes; also titled Türk Sanatı, it appeared in a number of editions in the 1980s and 1990s. 